\section{Call for international community to protect children in Kosovo}

Negin Shamsian, York

The international community has a duty to find a way of protecting all children, of whatever ethnic origin, remaining in Kosovo, Professor David Southall, consultant paediatrician at the North Staffordshire Hospital, Stoke on Trent, told the annual general Paediatrics and Child Health in York earlier this month.

Professor Southall, director of Child Advocacy International, was reporting on his recent visit to Kosovo. Child Advocacy International, a humanitarian aid organisation dedicated to providing hospital care for children in areas of extreme poverty and armed conflict, has recently withdrawn its team of doctors, including a child psychiatrist, a general practitioner, and a paediatrician, from Kosovo to northern Albania. The team had been in Kosovo since last October.

Problems faced by sick or injured children will have increased if reports that the main hospital in Pristina had been closed or destroyed turn out to be correct, he said.

Professor Southall highlighted the fact that there had been no aid in Kosovo since the air strikes and emphasised that the meeting of the Royal College of international community had to ensure that urgent humanitarian aid was ready at the borders, should a peace initiative succeed and aid workers regain access to the province.

Given the situation reported by refugees, Professor Southall thought it likely that medical aid within the province had now ended and that conditions for all children, particularly those who were ill or injured would be appalling. Kosovo at the present was "sheer hell for children. There is universal fear. Many children have lost their parents and siblings, have no food and

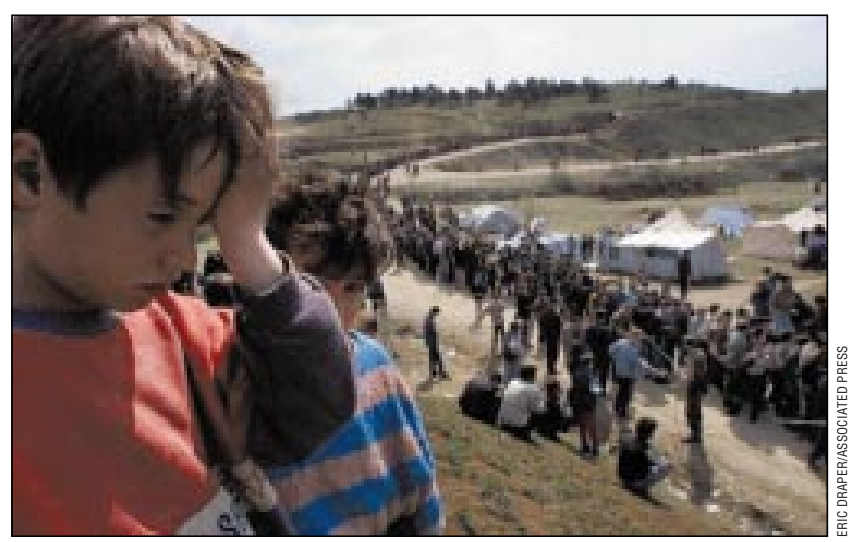

Kosovo's children are in need of medical care back in Kosovo, to protect and help children of all ethnic backgrounds. He felt that doctors should be advocating an immediate peace settlement.

Dr Charles Shepherd, a consultant paediatrician from Portadown, northern Ireland, said: "Britain has excellent doctors able to provide urgent help but unable to leave owing to the policies of NHS hospital trusts."

Anybody wishing to donate funds to Child Advocacy International's project in Kukes Hospital in northern Albania, can contact the organisation on 01782712599 . are seriously ill."

Professor Southall concluded by stating that paediatricians were urgently required to work not only in Albania and Macedonia with the refugees but also to be ready and willing to work

\section{NHS Direct will cover England by end of 2000}

Linda Beecham, $B M J$

The health secretary, Frank Dobson, has announced that NHS Direct-the nurse led 24 hour telephone helpline-will be available throughout England by the end of 2000. It currently operates from nine existing sites, giving 10 million people access to the service, and there are plans to launch another seven this year. It is also proposed that the service will move into new activities-for example, health promotion, the establishment of 200 information points, the production of a health guide, and NHS Direct on the internet.
Independent research by the University of Sheffield shows that although NHS Direct achieved high degrees of user satisfaction, call volumes were lower than expected and some callers were unhappy with the large number of questions asked during a call.

The researchers found that there was little useful literature on the effects of a helpline on the nature and volume of demand for health care.

There were wide differences in the pattern of advice between sites, as shown by the proportion of callers told to contact the accident and emergency service or their GP. Figures also showed that calls to ambulance services had not been affected.

The British Medical Association's General Practitioners Committee, which represents all GPs, is concerned that the expansion of the scheme$£ 280 \mathrm{~m}(\$ 448 \mathrm{~m})$ has been allocated over three years for NHS Direct and walk in health centres (p 1149)-will divert funds away from other parts of primary care.

The BMA admits that the project could reduce some out of hours work, but at its meeting last week some speakers thought it an inappropriate use of money. Dr Eric Rose, a GP in Buckinghamshire, said, "There is no costing and no evidence of the impact on other services." $\mathrm{He}$ told the committee that the centre at Milton Keynes had little work.

But Dr Judy Gilley, one of the committee's negotiators, said that having called for their workload to be reduced GPs must not appear Luddite. "We have got to negotiate how NHS Direct and walk in centres will work in parallel with our work."

\section{Trusts are failing to check on locums}

Douglas Carnall, BMJ

On any one day 3500 locums are at work in NHS trusts at an annual cost of $£ 214 m(\$ 342 \mathrm{~m})$, according to the latest Audit Commission report. The commission suggests that this bill could be reduced by as much as $10 \%$, mainly by minimising the fees paid to agencies, but its main concern is the quality of care provided by locums.

Although there have been several reports suggesting that the recruitment and induction procedures for locum doctors need to be improved, there is little evidence of this having happened.

Professional qualifications, past criminal convictions, and references are still often not checked despite a catalogue of high profile cases in recent years in which locums were found to have performed inadequately. Only $36 \%$ of trusts have acted on a 1997 NHS Executive report that suggested that all locums should have a structured assessment at the end of each period of work.

Whether this assessment schedule is realistic is open to question. According to the commission, half of all locum episodes are for contracts of 48 hours or less, and half of these take place at night or at weekends when supervision from senior staff is less likely to be available.

"Consultants admitted that they often don't even meet the locum," said one of the authors of the report, Anita Houghton, associate director of health studies at the commission, "never mind put themselves in a position to form an assessment of their clinical skill."

One factor that prevents locums from providing their best care is inadequate induction. Around a quarter of locums reported poor or nonexistent induction procedures at the start of a job.

The report, Cover Story: The Use of Locum Doctors in NHS Trusts, is available from the Audit Commission, 1 Vincent Square, London SW1P 2PN or at www.audit-commission.gov.uk. 